\title{
Understanding the Market in Higher Education in Africa
}

\author{
Table of Content
}

\section{Introduction}

Chapter 1: Understanding the Market in Higher Education in Africa

Emmanuel Mogaji, Felix Maringe, Robert Ebo Hinson

\section{Theme 1: Private and Government Involvement}

Chapter 2: Public vs Private Universities in Nigeria: Market Dynamics Perspective. Sunday Olaleye, Dandison Ukpadi, Emmanuel Mogaji

Chapter 3: Government Policies on Education in Africa Oluseyi Ajayi, Babatunde Abina, Azeez Lawal

Chapter 4: Addressing the Challenges of Higher Education in Africa: The role of African Governments, African Development Bank, and Business Corporations Operating in Africa

Taiwo Soetan

Chapter 5: Towards an Understanding of Islamic Private Universities in Africa. Adam Sirajudeen, Thomas Wayne, Emmanuel Mogaji

\section{Theme 2: Students and Staff as Stakeholders}

Chapter 6: Partnerships with Universities in South Africa: Challenges and Opportunities for Student and Staff Mobility Samia Chasi

Chapter 7: Marketing Higher Education: Creating value for refugee students Otilia Chiramba, Felix Maringe

Chapter 8: Marketing Higher Education Through Work-Readiness Programmes Lovisa Nghipandulwa, Elina Amadhila, Ezekiel Kwembeya

\section{Theme 3: Positioning for Added Advantage}

Chapter 9: Paving the Way for World Domination: Analysis of African Universities' Mission Statement

Savdeep Vasudeva, Emmanuel Mogaji

Chapter 10: Typology of Nigeria Universities: A Strategic Marketing and Branding Implication

Temitope Farinloye, Ogechi Adeola, Emmanuel Mogaji 
Chapter 11: University League Tables and Ranking Systems in Africa: Emerging Prospects, Challenges and Opportunities

Ruth Kiraka, Felix Maringe, Watiri Kanyutu, Emmanuel Mogaji

\section{Theme 4: Marketing Strategies for Universities}

Chapter 12: Training the Marketers for Implementing New Marketing Strategy: A Case from the University of Ghana.

John Boateng

Chapter 13: Marketing mix in a heterogenous Higher Education Market: A Case of Africa

Elizabeth Ndofirepi, Temitope Farinloye, Emmanuel Mogaji

Chapter 14: Marketing Muslim Universities: Challenges and Opportunities with Specific Reference to the African Case Lo Mbaye

\section{Conclusion}

Chapter 15: Marketisation in higher education in Africa: new directions for a decolonising continent

Emmanuel Mogaji, Felix Maringe, Robert Ebo Hinson 


\section{Editors}

Emmanuel Mogaji holds a $\mathrm{PhD}$ in Marketing, and he is a Lecturer in Advertising and Marketing Communications at the University of Greenwich, and a Fellow of the Higher Education Academy (HEA) and a Certified Management \& Business Educator (CMBE). Emmanuel's primary area of interest is ABCDE of Marketing Communications - Advertising, Branding, Communications, Digital and Ethics, with a strong focus on higher education and financial services marketing. He recently authored a book on Emotional Appeals in Advertising Banking Services published by Emerald. He has published several peer-reviewed journals articles and book chapters and presented his work in many national and international conferences. In recognition of his research productivity, was awarded the 2019 Emerald Literati Highly Commended Paper Award for a co-authored paper published in Asia Pacific Journal of Marketing and Logistics. He has co-edited books on marketing higher education in Africa published by Routledge and Springers Nature.

Felix Maringe is a Professor, Head of Wits School of Education Research and Assistant Dean Internationalisation and Partnerships at the University of the Witwatersrand. $\mathrm{He}$ is also a Visiting Fellow within Southampton Education School at the University of Southampton. His research concentration is in the area of Globalisation and Internationalisation of HE within the broad remit of leadership and management. He teaches on PGCE, MA Ed and Doctoral programmes. Felix is the EdD Lead tutor at the University of Southampton with specific responsibility for the Leadership stratum of the Doctorate programme. He is currently leading research into the impact of Globalisation on Higher Education through a global survey of universities in different parts of the world. With a publication record of more than fifty outputs, his core area of research interest is in leadership in education, the impact of globalisation on education, and the management of transforming educational spaces. Currently, he is involved in a large-scale project on school improvement with the Mpumalanga Department of Education.

Robert Ebo Hinson is a Professor and a past Head of the Department of Marketing \& Entrepreneurship at the University of Ghana Business School. Professor Hinson has been a consultant to several local and international institutions in Ghana. Professor Hinson started his professional career in advertising and has since become an academic taught a diversity of undergraduate and postgraduate courses. Apart from his experience in teaching, Prof. Hinson has a keen interest in research and in recognition of his research productivity, was awarded the 2008 Emerati Highly Commended paper Award for a co-authored paper published in Corporate Governance, the 2009 Journal of African Business Best Paper Award, the 2010 Emerati Outstanding Paper Award for a co-authored paper published in the Journal of Research in Interactive Marketing. Professor Hinson is published in or has had papers accepted for publication in rated journals like the International Journal of Public Sector Management, Internet Research, International Journal of Bank Marketing, Journal of Financial Services Marketing, Journal of Business and Industrial Marketing, and the Thunderbird International Business Review. 


\section{List of Contributors}

Babatunde Abina is a lecturer at the Department of Marketing and Consumer Studies, School of Economics, University of Ibadan, Nigeria, with over six years' experience in teaching marketing and management related courses. Earned PhD degree in Business Administration with specialisation in Marketing at the University of Ilorin, M.Sc. in Marketing and B.Sc. Mass Communication from the University of Lagos. His research interest is in the area of branding, advertising and marketing communications.

Ogechi Adeola is an Associate Professor of Marketing at the Lagos Business School (LBS), Pan-Atlantic University, Nigeria. She is also the Academic Director, LBS Sales \& Marketing Academy. Her research interests include tourism and hospitality marketing, branding and marketing communications, and digital marketing strategies in sub-Saharan Africa. She has published academic papers in top-rated scholarly journals. Her co-authored papers won Best Paper Awards at conferences in 2016, 2017 and 2018. She holds a doctorate in Business Administration (DBA) from Manchester Business School, United Kingdom and started her career at Citibank Nigeria, spending approximately 14 years in the financial sector before moving into academia.

Oluseyi Ajayi is a lecturer in the Department of Marketing and Consumer Studies, School of Economics, University of Ibadan. He has a first degree in Business Administration, MBA, MSc. Also, $\mathrm{PhD}$ in the same field of study. He specialises in strategic management and marketing. His research papers have been published in recognised national and international journals. He has more than six years lecturing experience.

Elina Amadhila holds a PhD in Development Finance and has two years of experience as a Lecturer in the Department of Management Sciences at the University of Namibia. She also has experience in training and supervising undergraduate, MBA students and PhD students. $\mathrm{Dr}$ Amadhila has written and published papers in the field of development, welfare and Education. She is a member of the Work-readiness Task Force at the University of Namibia.

John Boateng holds a PhD from the Pennsylvania State University (PSU), USA. He joined the University of Ghana as Lecturer in 2013. He completed a postdoctoral research experience with the University of Michigan from August 2014 to February 2015. In 2016, he was promoted to the rank of Senior Lecturer. He is a recipient of research grants from the Pennsylvania State University, University of Ghana (UG), University of Michigan (U-M), Council for the Development of Social Research in Africa (CODESRIA). Also, other funding agencies. His research interests include education marketing, instructional supervision and management and curriculum development.

Samia Chasi is a practitioner-scholar with 20 years of experience in higher education internationalisation through positions in international offices of German and South African universities, an agency of the European Commission as well as representations of the DAAD, Nuffic and the British Council in South Africa. She currently serves as Strategic Advisor to the International Education Association of South Africa (IEASA). Samia Chasi holds a Doctor of Philosophy in Education (University of the Witwatersrand, Johannesburg), a Master of Philosophy in Engineering Management (University of Johannesburg) and a Master of Arts in English, Russian and Sociology (University of Rostock, Germany). 
Otilia Chiramba is a doctoral candidate at Witwatersrand University. She is an emerging academic who has impeccable interest in researching underprivileged groups such as refugee students in higher education and young scientists. She has co-authored and published an article in the European Education journal. She has also written four chapters which are in press. Otilia has worked for a global research project, the Global State of Young Scientists (GloSYS) collected and analysed qualitative data and has co-authored in writing the narratives yet to be published. She has also been involved with tutoring undergraduates and postgraduate students at the university.

Temitope Farinloye has a first degree from the University of Bedfordshire, Luton and presently working towards her master's degree at Kings College, London. She presently works at Questbury Research Services as a Research Associate. Her research interests are in the marketing of higher education, social media and qualitative analyses of user-generated contents. She has published her works in reputable journal articles, book chapters and presented her work at local and international conferences.

Robert Ebo Hinson is a Professor and a past Head of the Department of Marketing \& Entrepreneurship at the University of Ghana Business School. Professor Hinson has been a consultant to several local and international institutions in Ghana. Professor Hinson started his professional career in advertising and has since become an academic taught a diversity of undergraduate and postgraduate courses. Apart from his experience in teaching, Prof. Hinson has a keen interest in research and in recognition of his research productivity, was awarded the 2008 Emerati Highly Commended paper Award for a co-authored paper published in Corporate Governance, the 2009 Journal of African Business Best Paper Award, the 2010 Emerati Outstanding Paper Award for a co-authored paper published in the Journal of Research in Interactive Marketing. Professor Hinson is published in or has had papers accepted for publication in rated journals like the International Journal of Public Sector Management, Internet Research, International Journal of Bank Marketing, Journal of Financial Services Marketing, Journal of Business and Industrial Marketing, and the Thunderbird International Business Review.

Watiri Kanyutu is a final year Doctoral student at the Nelson Mandela University, Business School. The title of her thesis is "A Ranking Framework for South African Higher Education Institutions". She holds a Masters of Business Administration degree (MBA) and lectures Marketing Management at the Nelson Mandela University Business School.

Ruth Kiraka is an Associate Professor of Strategy \& Entrepreneurship at the Strathmore University, Kenya. She earned her PhD from Victoria University, Melbourne, Australia; MSc from Wageningen University, the Netherlands; and BSc from Egerton University, Kenya. She has published two books, two conference proceedings, two research reports, over 25 journal articles and book chapters and 12 case studies. She has supervised several $\mathrm{PhD}$ and masters' students. Her teaching performance won her a University teaching excellence award. She has served as an external examiner for Erasmus University, the Netherlands and external peer reviewer for National Council of Higher Education, Namibia and Kenya's Commission for University Education. Prof. Kiraka is a journal reviewer for Eastern Africa Social Science Research Review; International Journal of Knowledge, Culture and Change Management; Knowledge and Process Management and International Academy of African Business and Development. 
Ezekiel Kwembeya holds a $\mathrm{PhD}$ in Botany and has over seven years of experience as a Senior Lecturer in the Department of Biological Sciences at the University of Namibia. He has experience in training and supervising undergraduate, MSc students and $\mathrm{PhD}$ students. $\mathrm{Dr}$ Kwembeya is currently doing a Postgraduate Diploma in Higher Education and has a keen interest in Higher Education Research. He has published several study guides and instructional materials for his courses over the years and is a member of the Work-readiness Task Force at the University of Namibia.

Azeez Lawal is a lecturer at the Department of Business Administration, Al-Hikmah University, Ilorin, Nigeria. He is a Fellow of the African Young Leadership Program of Accra Business School, Ghana and multiple scholars of the Lagos Business School's Sustainability Centre in Nigeria. He is also a member of the National Institute of Marketing of Nigeria, Chartered Institute of Personnel Management of Nigeria, Teachers Registration Council of Nigeria and the International Society for Development and Sustainability, Japan. He has 13 years cross-industry working experience in telecommunication, banking, academia and the social sector and has several pieces of research in print at international and local conferences, peer-reviewed journals and books. His areas of specialisation are Marketing, Entrepreneurship and General Management.

Mbaye Lo is an Associate Professor of the Practice of Asian and Middle Eastern Studies at the Duke University. Dr Lo, a recipient of the Duke Alumni Distinguished Undergraduate Teaching Award, is the Arabic Program Coordinator and Director of Duke in the Arab World Academic Program. He works primarily on Arabic discourse with a sub-specialisation in the sociology of Islam, Islamic militancy, theories of civil society, in addition to the development of Arabic language and culture in Africa, Modern Standard Arabic (MSA) \& oral proficiencybased language teaching and testing. One of his books is Muslim Institutions of Higher Education in Postcolonial Africa (2015) published by Palgrave.

Felix Maringe is a Professor, Head of Wits School of Education Research and Assistant Dean Internationalisation and Partnerships at the University of the Witwatersrand. He is also a Visiting Fellow within Southampton Education School at the University of Southampton. His research concentration is in the area of Globalisation and Internationalisation of HE within the broad remit of leadership and management. He teaches on PGCE, MA Ed and Doctoral programmes. Felix is the EdD Lead tutor at the University of Southampton with specific responsibility for the Leadership stratum of the Doctorate programme. He is currently leading research into the impact of Globalisation on Higher Education through a global survey of universities in different parts of the world. With a publication record of more than fifty outputs, his core area of research interest is in leadership in education, the impact of globalisation on education, and the management of transforming educational spaces. Currently, he is involved in a large-scale project on school improvement with the Mpumalanga Department of Education.

Emmanuel Mogaji holds a $\mathrm{PhD}$ in Marketing, and he is a Lecturer in Advertising and Marketing Communications at the University of Greenwich, and a Fellow of the Higher Education Academy (HEA) and a Certified Management \& Business Educator (CMBE). Emmanuel's primary area of interest is $\mathrm{ABCDE}$ of Marketing Communications - Advertising, Branding, Communications, Digital and Ethics, with a strong focus on higher education and financial services marketing. He recently authored a book on Emotional Appeals in Advertising Banking Services published by Emerald. He has published several peer-reviewed journals articles and book chapters and presented his work in many national and international 
conferences. In recognition of his research productivity, was awarded the 2019 Emerald Literati Highly Commended Paper Award for a co-authored paper published in Asia Pacific Journal of Marketing and Logistics. He has co-edited books on marketing higher education in Africa published by Routledge and Springers Nature.

Elizabeth Ndofirepi is an Academic Advisor in the Office of Student Success Faculty of Health Science, University of the Witwatersrand, South Africa. She is a holder of a PhD on student experiences in Higher Education. She has served as a Project Manager, teacher, head of school, lecturer in Teacher's College and Polytechnic, university tutor and training officer in the Public Service Commission as well as Head of Department in Higher Education Institutions. Her current research interests are in issues of Higher Education. She has coauthored and published four journal articles, two book chapters and presented numerous papers at conferences.

Lovisa Nghipandulwa holds a Master degree in Social Work and is currently pursuing her $\mathrm{PhD}$ focusing on industry-based supervision of students. She has nine years of experience in career development \& graduates work readiness at the University of Namibia. She has developed the Cooperative and Work-Integrated Education draft Policy for the University of Namibia and is the chairperson of the Work Readiness Program Task Force at the University of Namibia. She has a strong interest in youth development work and serves as an external moderator in this area for the Namibian College of Open Learning

Sunday Olaleye is a Postdoctoral Researcher at the Department of Marketing, Management and International Business of Oulu Business School, University of Oulu. He had Master of Science Degree in Information Systems from the Abo Akademi University, Turku, Finland, Master of Business Administration (MBA), Lapland University of Applied Sciences, Tornio, Finland, NMS iICT Certificate, Innovation and Entrepreneurship, Nordic Master School of Innovative ICT, Turku Centre for Computer Science (TUCS), Turku, Finland. He has presented papers at conferences and published in academic journals. His research interests are emerging mobile technologies, tablet commerce, mobile commerce, circular economy and mobile apps.

Adam Sirajudeen is a Professor of Afro-Arabic Historiography and former Dean, Faculty of Humanities, Management \& Social Sciences and current head of Department of Languages at the Federal University of Kashere, Gombe State, Nigeria. He holds a PhD Afro-Arabic Literary Historiography. Member of Editorial Board,/Reviewer of various academic journals. His previous works include Teaching Arabic As A Second Language in Nigeria, The Dynamics of Afro-Arabic Cultural Resurgence in the Shadow of Civilization and Islamic-Oriented University in Nigeria: Triumphs and Travails", in Muslim Institutions of Higher Education in Postcolonial Africa published Palgrave Macmillan, 2016.

Taiwo Soetan obtained his PhD from the University of North Dakota, Grand Forks, U.S, two masters' degrees from the University of Manitoba, Winnipeg, Canada, and Strathclyde Business School, University of Strathclyde, Glasgow, U.K, and his first degree from the University of Ibadan, Nigeria. He was a past Vice Chairman of the Canadian Institute of Marketing, and he presently lectures in the Business Administration program at the School of Business \& Applied Arts, Red River College, Winnipeg, Canada.

Dandison Ukpadi is currently on the concluding stages of his $\mathrm{PhD}$ in Marketing at the University of Jyväskylä in Finland. Dandison's research interest centres on understanding consumers' behavioural use of emerging technologies such as social media, mobile applications 
and robotics/artificial intelligence. His research context focuses mostly on tourism; however, he makes occasional forays into banking and retail. In line with his educational experiences that cut across countries in Africa, Europe and Australia, so also has he gained over ten years of working experience in various roles including the academia as a lecturer/researcher in Africa, United Kingdom, Australia and Finland.

Savdeep Vasudeva is as an Assistant Professor in the Department of Business Management of DAV Institute of Engineering \& Technology, India. He holds a PhD in Management and has contributed different research papers in International Journals. He has a keen interest in the field of consumer behaviour and strategic marketing involving the understanding of behavioural issues in case of technology-based products and services. He also owns an MBA degree with specialization in Information Technology and a B.Sc. degree (with Economics and Computer Science). In addition to this, he possesses a Certificate in Computing from IGNOU, New Delhi. He has a total work experience of above 19 years. It is comprised of more than 13 years of teaching and six years of industrial experience. During his stay in industry, he has worked in different techno-managerial capacities and afterwards is primarily involved in teaching of MBA students in his academic career.

Thomas Wayne is a Research Associate at Questbury Research Services. He has over ten years of industry experience in advertising and marketing communications. He has worked on various brand development and integration projects. His academic research interests are in marketing with a specific focus on higher education, financial services and sports. He has published her works in reputable journal articles, book chapters and presented his works at conferences. 